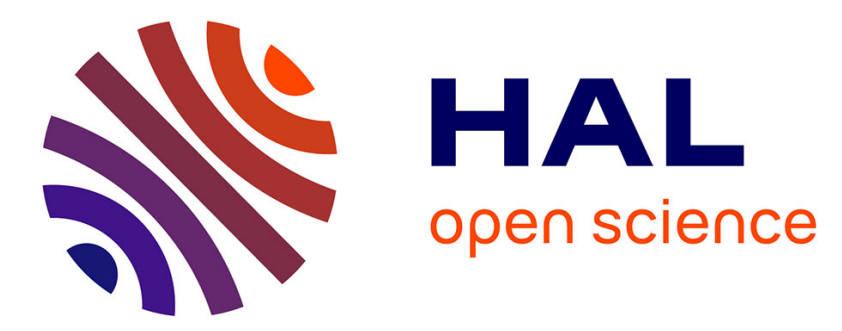

\title{
BEHAVIOUR OF MAGNETIC DOMAIN WALLS IN PRESENCE OF STRUCTURAL DEFECTS IN HIGH PURITY IRON
}

\author{
B. Astie, J. Degauque
}

\section{- To cite this version:}

B. Astie, J. Degauque. BEHAVIOUR OF MAGNETIC DOMAIN WALLS IN PRESENCE OF STRUCTURAL DEFECTS IN HIGH PURITY IRON. Journal de Physique Colloques, 1985, 46 (C10), pp.C10-721-C10-724. 10.1051/jphyscol:198510158 . jpa-00225365

HAL Id: jpa-00225365

https://hal.science/jpa-00225365

Submitted on 1 Jan 1985

HAL is a multi-disciplinary open access archive for the deposit and dissemination of scientific research documents, whether they are published or not. The documents may come from teaching and research institutions in France or abroad, or from public or private research centers.
L'archive ouverte pluridisciplinaire HAL, est destinée au dépôt et à la diffusion de documents scientifiques de niveau recherche, publiés ou non, émanant des établissements d'enseignement et de recherche français ou étrangers, des laboratoires publics ou privés. 


\title{
BEHAVIOUR OF MAGNETIC DOMAIN WALLS IN PRESENCE OF STRUCTURAL DEFECTS IN HIGH PURITY IRON
}

\author{
B. ASTIE AND J. DEGAUQUE \\ Laboratoire de Physique des Solides, associé au CNRS, INSA, \\ Avenue de Rangueil, 31077 Toulouse Cedex, France
}

Résumé - A partir de la mesure du frottement intérieur magnétomécanique, on a étudié l'influence de différents défauts structuraux (dislocations, joints de grains, interstitiels de carbone et carbures précipités) sur le comportement des parois de Bloch à $90^{\circ}$ dans le fer pur. On détermine la distribution de contraintes internes locales et le facteur de forme du cycle d'hystérésis magnétomécanique, définis dans le modèle de Smith et Birchak [1\}. Leurs variations sont reliées aux modifications de densité et d'arrangement des défauts de structure étudiés.

Abstract - Using magnetomechanical damping experiments, we have studied the influence of various structural defects (dislocations, grain boundaries, interstitial carbon atoms and precipitated carbides) on the hysteretic behaviour of $90^{\circ}$ magnetic domain walls (DW's) in pure iron. The distribution of internal local stresses and the shape factor of the magnetomechanical hysteresis cycle, as defined in the model of Smith and Birchak [1], have been examined. Their variations are linked to the modifications of density and arrangement of structural defects.

I - INTRODUCTION - In pure iron, we have already studied the influence of dislocations, grain boundaries, interstitial carbon atoms and precipitated carbides on the magnetomechanical damping $\mathrm{Q}^{-1}$, which depends only on the behaviour of $90^{\circ}$ DW's [2]. When plotted as a function of the shear stress $\mathcal{\tau}$, this damping, which has been measured on a reversed torsion pendulum, shows a maximum. Its position gives the average internal stress $\sigma_{\text {j }}$ opposed to the displacements of the $90^{\circ} \mathrm{DW} / \mathrm{s}$ [1]. Looking at the whole of the $Q^{-1}(\tau)$ variation, it is possible to deduce the distribution function $N$ of the local internal stresses revealed by the irreversible displacements of $90^{\circ}$ DW's. Moreover if the calculation of the magnetomechanical losses at the maximum damping can be reached for every distribution function $N$, the shape factor $K$ of the hysteresis loop can be deduced from the value of $Q^{-1} M^{*}$ The magnetomechanical energy losses are directly proportional to $K$ [1]. In this paper, after a brief description of the variations of $\mathrm{Q}_{M}^{-1}$ and $\sigma_{i}$ with the arrangements of the structural defects studied, we give first the results concerning the influence of the modifications of $\mathrm{N}$ on the determination of $K$. Then the variations of these quantities are studied in order to describe the features of the behaviour of $90^{\circ} \mathrm{DW} / \mathrm{s}$ interacting with various structural defects in polycrystalline iron.

II - DETERMINATION OF THE SHAPE FACTOR $K^{*}$ - The distribution function of the local stresses $N()$ is obtained by derivation starting from the values of $Q^{-1}(\tau)$

* The results given here can be found in the thesis of B. Astie (D.E., Univ.

Paul Sabatier Toulouse) (to be published). 


$$
N(\tau) \propto \frac{1}{\tau} \frac{d}{d \tau}\left(\tau^{2} Q^{-1}\right)
$$

$N(\tau)$ is a distribution function, normalized to 1 . It is zero at $\tau=0$, goes towards zero when $\tau \rightarrow \infty$ and has only one maximum $N_{M}$ at $\tau=\tau N_{M} \cdot N$ can be expressed in terms of the dimensionless parameters $\tau / \tau N_{M}$ and $N / N_{M^{*}}$ In this representation it is useful to define a "distribution width" $L$, which is the distance between the two values of $\tau / \tau N_{M}$ corresponding to $N / N_{M}=0.5$. For the distribution function $N$, this width is called Lr. According to [1] $\mathrm{Q}_{M}^{-1}$ is given by the relation (2)

$$
\mathrm{Q}_{M}^{-1}=K \frac{\mathrm{E} \lambda_{100}}{\pi} \frac{\mathrm{C}_{\mathrm{N}}}{\sigma_{\mathrm{i}}}
$$

where $E$ is the Young's modulus, $\lambda_{100}$ the saturation magnetostriction and $C_{N}$ a parameter which can be computed for every distribution function $N$. For the whole range of variation of $\mathrm{L}$ studied, the relative variation of $\mathrm{C}_{\mathrm{N}}$ is less than $7 \%$. So $\mathrm{K}$, which is deduced from (2), depends mainly on the quantity $\left(Q_{M}^{-1} \times \sigma_{1}\right)$. The relative accuracy in the determination of $\mathrm{Lr}$ and $\mathrm{K}$ is around 0.07 .

\section{III - ARRANGEMENTS OF THE STRUCTURAL DEFECTS STUDIED}

Dislocations - Different arrangements of dislocations are built by tensile strainings at $300 \mathrm{~K}$ with strain levels between 0 and $16.4 \%$. Three stages appear on the stress strain curve which correspond respectively to the creation of isolated dislocations
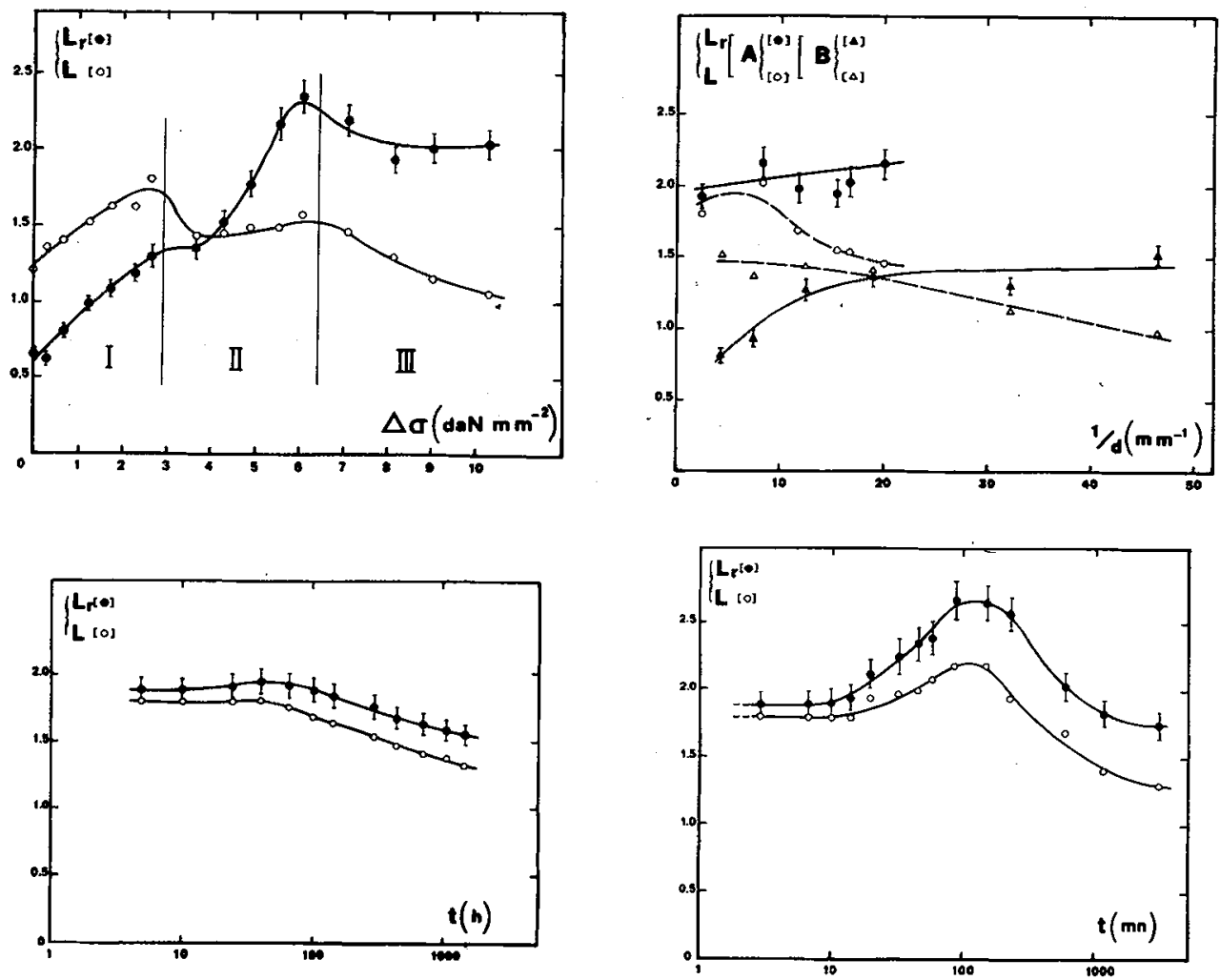

Fig. 1 - Lr and $L$ vs - strain hardening (a) - reciprocal grain size (b) - annealing time in $\mathrm{h}$ at $40^{\circ} \mathrm{C}(\mathrm{c})$ and in $\mathrm{mn}$ at $200^{\circ} \mathrm{C}$ (d). Lr is given in daN.mm- ${ }^{2}$. 
(stage I), the clustering of dislocations into tangles (stage II), and the onset of a cellular structure (stage III) [2]. In the three stages $\sigma_{i}$ and $1 / Q_{M}^{-1}$ increase linearly with the strain hardening $\Delta \sigma$ (which is proportional to $\sqrt{\mathrm{D}}$, with $\mathrm{D}$ density of created dislocations) but with different slopes.

Grain boundaries - By recrystallisations at different temperatures, two sets (A and B) of specimens are obtained with different dislocation densities. The-grain size $d$ is homogeneous throughout every specimen and increases from $0.021 \mathrm{~mm}$ to $0.425 \mathrm{~mm}$. $\sigma_{\mathrm{i}}$ and $1 / \mathrm{Q}_{\mathrm{M}}^{-1}$ increase linearly with the density of grain boundaries. The slope of these variations is nearly similar for the two sets but the level is higher for set $A$ which corresponds to the higher dislocation density [2].

Fe-C alloy - A pure iron-carbon alloy (180 ppm.w carbon) is annealed at two temperatures. At $40^{\circ} \mathrm{C}$ only precipitates of $\varepsilon$ carbide appear, whose density increases in function of time. $1 / \mathrm{Q}^{-1}$ decreases when $\sigma_{i}$ remains practically constant. This is connected with the counterbalance of the anchoring effect of precipitates by a "release effect" due to the decrease of the restoring force of the interstitial carbon atoms on the $90^{\circ} \mathrm{DW} ! \mathrm{s}$ [3]. At $200^{\circ} \mathrm{C}$, after $10 \mathrm{mn}$ of annealing, the precipitation of $\varepsilon$ carbide is followed by that of cementite. $1 / \mathrm{Q}_{M}^{-1}$ and $\sigma_{i}$ increase markedly at the beginning of this second stage, which is connected with the efficient anchoring effect of precipitates whose size becomes comparable to the DW's width [3].
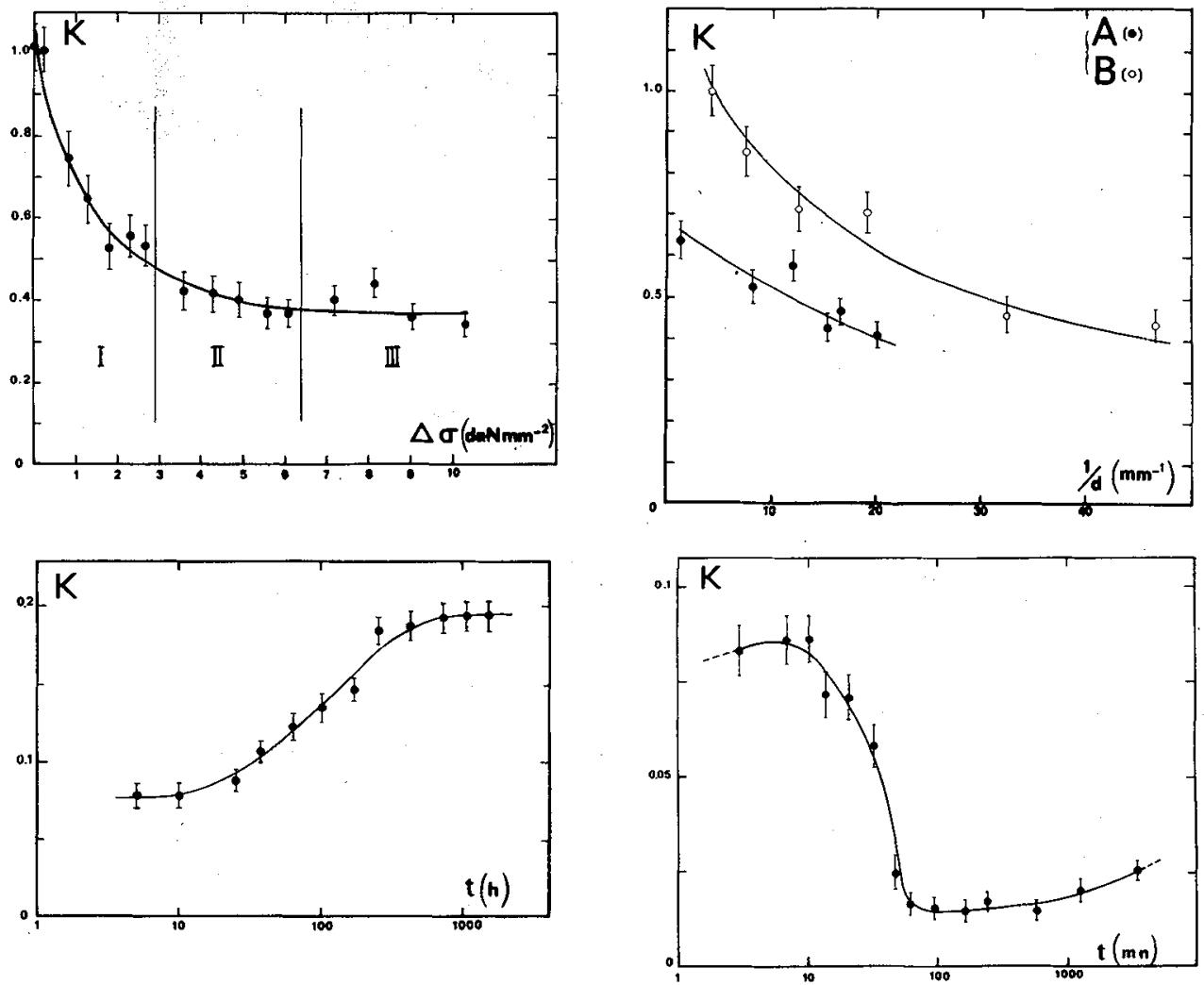

Fig. 2 - K vs - strain hardening (a) - reciprocal grain size (b) - annealing time in $h$ at $40^{\circ} \mathrm{C}$ (c) and in $\mathrm{mn}$ at $200^{\circ} \mathrm{C}$ (d). 


\section{IV - EXPERIMENTAL RESULTS AND DISCUSSION}

Dislocations - Lr increases in the stages I and II with the density D of created dislocations and is constant in stage III (Fig. 1 a). The corresponding values of $L$ show that the reduced distribution function of internal stresses depends more on the arrangement of isolated dislocations than on the density. $N / N_{M}$ becomes less homogeneous ( $\mathrm{L}$. increases) in stage $\mathrm{I}$, when isolated dislocations are created. Then $\mathrm{N} / \mathrm{N}_{\mathrm{M}}$ keeps its shape in stage II, when the newly created dislocations cluster in tangles. In stage III, N/N $\mathrm{N}_{\mathrm{M}}$ becomes homogeneous again, when cells of dislocations are forming, with decreasing density of isolated dislocations inside them.

The coefficient $K$ decreases uniformly when $D$ increases, with a stronger rate in stage I (Fig. 2 a). The shape of the magnetomechanical loop is mainly affected by the isolated dislocations and much less by tangles or walls of dislocations.

Grain boundaries - $I$ decreases similarly for the two sets A and B (Fig.l b). So, the reduced distributions $\mathrm{N} / \mathrm{N}_{\mathrm{M}}$ show the same trend towards homogeneity when the density of grain boundaries, increases. The distributions corresponding to set $B$ are more homogeneous due to the lower density of dislocations. The coefficient $K$ decreases with the average grain size (Fig. 2 b). $K$ is also affected by the higher density of dislocations of set A.

Fe-C alloy - For the annealing at $40^{\circ} \mathrm{C}, \mathrm{Lr}$ and $\mathrm{L}$ have similar variations showing that the reduced $N / N_{M}$ becomes more homogeneous when the content of interstitial carbon atoms decreases and the density of $\varepsilon$ carbides increases (Fig.1 c). The surprising behaviour of the shape factor $\mathrm{K}$ (Fig.2 $\mathrm{C}$ ) which is different from that observed above, is attributed to the "release effect" previously discussed.

According to the variations of $\mathrm{Lr}$ and $\mathrm{L}$, the precipitation of cementite, during annealing at $200^{\circ} \mathrm{C}$, is linked to a decrease of the homogeneity of the reduced distribution $\mathrm{N} / \mathrm{N}_{\mathrm{M}}$, when the size of the precipitates becomes comparable to the width of DW's (Fig.1 d). At longer annealing times ( $t>500 \mathrm{mn}$ ), when the density of precipitates decreases, $N / N_{M}$ is more homogeneous. The increase of $K$ at the beginning of the annealing is due to the "release effect" (Fig.2 d). $\mathrm{K}$ decreases markedly (for $t>20 \mathrm{mn}$ ), as the density of precipitates does not change very much [3]. So the decrease of $K$ is connected to the increasing compatibility of the size of the precipitates and the DW's width. The cementite carbides act as pinning centers which induce strong local perturbations on the $90^{\circ} \mathrm{DW} ' \mathrm{~s}$.

V - CONCLUSION - In pure iron, structural defects act differently, according to their density and their arrangement, on the behaviour of $90^{\circ}$ DW's. Isolated dislocations, grain boundaries and cementite carbides of size comparable to the width of the DW's, affect markedly the homogeneity of the distribution of internal stresses, opposed to the displacements of $90^{\circ} \mathrm{DW}$ 's, and the shape factor of the magnetomechanical loop. This shape factor is more sensitive to the braking effect of the interstitial carbon atoms than to the anchoring effect by the precipitates of $\mathcal{E}$ carbide.

\section{REFERENCES}

[1] Smith, G.W., Birchak, J.R., J.A. Phys., 40, 13 (1969) 5174

[2j Degauque, J., Astié, B., The Mech. Beh. of Electr. Sol. Cont., Symp. Paris 1983, G.A. Maugin ed. (N. Holland 1984) 275

[3] Astié, B., Degauque, J., (Proc. ECIFUAS 3) C.C. Smith ed. (Pergamon Press 1980) 